\title{
PENGARUH KREATIVTAS GURU, LINGKUNGAN SOSIAL, DAN MOTIVASI BELAJAR TERHADAP PRESTASI BELAJAR EKONOMI PESERTA DIDIK
}

\author{
Yusdiana $^{1}$, Muhammad Azis ${ }^{2}$, Herman $^{3}$ \\ Mahasiswa Program Magister Prodi IPS, Pascasarjana Universitas Negeri Makassar \\ Email: yusdiana093@gmail.com \\ Fakultas Ekonomi, Universitas Negeri Makassar \\ Email: azis_feunm@yahoo.com \\ Fakultas Ilmu Sosial, Universitas Negeri Makassar \\ Email: hermanspdmsi1975@yahoo.com
}

\begin{abstract}
The study aimed to identify the direct influence of teachers' creativity, social environment, and learning motivation towards economic learning achievement of sudents. the study used survey method with quantitative approach. The population of the study was all students at SMAN 7 Soppeng in Soppeng district. Sample was selected by employing stratified sampling technique with sample proportional type. The instruments used to collect the data were quesytionnaire, observation, and documentation. The result of study reveal that there is no direct influence of teachers' creativity on learning achievement and there is indirect influence positively and significantly of teachers' creativity on learning achievement through learning motivation, there is direct influence positively and significantly of social environment on learning achievement and indirect influence positively and significantly of social environment on learning achievement through learning motivation, there is direct influence positively and significantly of teachers' creativity and social environment on learning motivation both partially and simultaneously, and there is direct influence positively and significantly of learning motivation on learning achievement.
\end{abstract}

Keyword: Economy learning achievement; Teachers' creativity; Social environment; Learning motivation

\begin{abstract}
Abstrak. Penelitian ini bertujuan untuk mengidentifikasi pengaruh kreativitas guru, lingkungan sosial dan motivasi belajar terhadap prestasi belajar ekonomi peserta didik. Penelitian menggunakan metode survey dengan pendekatan kuantitatif. Populasi dalam penelitian ini adalah seluruh siswa SMA Negeri 7 Soppeng Kabupaten Soppeng. Tekhnik pengambilan sampel adalah strata sampel (stratified sampling) dengan jenis proporsional sampel. instrument yang digunakan untuk mengumpulkan data adalah angket, observasi dan dokumentasi. Hasil penelitian menunjukkan bahwa (1) Tidak terdapat pengaruh langsung kreativitas guru terhadap prestasi belajar dan terdapat pengaruh tidak langsung yang positif dan signifikan kreativitas guru terhadap prestasi belajar melalui motivasi belajar, (2) Terdapat pengaruh langsung positif yang signifikan lingkungan sosial terhadap prestasi belajar dan pengaruh tidak langsung yang positif yang signifikan lingkungan sosial terhadap prestasi belajar melalui motivasi belajar, (3) Terdapat pengaruh langsung positif yang signifikan kreativitas guru dan lingkungan sosial terhadap motivasi belajar baik secara parsial maupun secara simultan, (4) Terdapat pengaruh langsung positif yang signifikan motivasi belajar terhadap prestasi belajar.
\end{abstract}

Kata kunci: Prestasi belajar ekonomi; Kreativitas guru; Lingkungan social; Motivasi belajar 
Yusdiana, Muhammad Azis, Herman, Pengaruh Kreatifitas Guru... $\mid 2$

\section{PENDAHULUAN}

Salah satu indikator keberhasilan proses belajar mengajar di sekolah adalah faktor pencapaian atau prestasi belajar siswa (Sudijono, 2011). Prestasi belajar atau faktor pencapaian digunakan sebagai salah satu bahan pertimbangan dalam penentuan nilai akhir, sebab prestasi atau pencapaian siswa yang dilambangkan dengan nilai-nilai hasil belajar pada dasarnya mencerminkan sampai sejauh mana tingkat keberhasilan yang telah dicapai oleh siswa dalam pencapaian tujuan pendidikan yang telah ditentukan bagi masing-masing mata pelajaran atau bidang studi.

Hal yang senada dikemukakan oleh Syaodih (Aini \& Taman, 2012) mengemukakan bahwa prestasi atau hasil belajar (achievement) merupakan realisasi atau pemekaran dari kecakapan-kecakapan potensial atau kapasitas yang dimiliki seseorang. Penguasaan hasil belajar oleh seseorang dapat dilihat dari perilakunya, baik perilaku dalam bentuk penguasaan pengetahuan, keterampilan berpikir maupun keterampilan motorik. Di sekolah, hasil belajar ini dapat dilihat dari penguasaan siswa akan mata pelajaran yang ditempuhnya.

Faktor-faktor yang mempengaruhi prestasi belajar diantaranya adalah faktor intern dan ekstern. faktor intern meliputi kecerdasan/intelegensi, bakat, minat dan motivasi. Adapun yang tergolong faktor ekstern yaitu keadaan keluarga, keadaan sekolah, lingkungan masyarakat, dan faktor waktu (Hakim, 2008)

Untuk dapat mengetahui keberhasilan proses kegiatan belajar mengajar, seluruh faktorfaktor yang mempengaruhi keberhasilan siswa dalam belajar harus diperhatikan. Mulai dari perilaku guru dalam mengajar, lingkungan sosial yang mendukung sampai dengan tingkah laku siswa sebagai timbal balik dari hasil sebuah pengajaran.

Berdasarkan hasil studi pendahuluan di SMA Negeri 7 Soppeng fakta yang terjadi di kelas XI IPS2 bahwa prestasi belajar ekonomi peserta didik di kelas tersebut setiap semesternya mengalami peningkatan dimana lebih dari $98 \%$ tuntas dalam mengikuti pembelajaran. Meskipun demikian masih ada beberapa orang peserta didik yang hanya mampu mencapai standar Kriteria Ketuntasan Minimal (KKM) bahkan ada yang tak mampu mencapai standar KKM. Hasil studi tersebut mengindikasikan prestasi belajar ekonomi di SMA Negeri 7 Soppeng masih perlu ditingkatkan.
Beberapa faktor yang paling berpengaruh dalam meningkatkan prestasi belajar peserta didik diantaranya adalah kreativitas guru dalam mengajar, lingkungan sosial peserta didik, dan motivasi belajar. sehingga untuk meningkatkan prestasi belajar peserta didik, maka ketiga faktor tersebut perlu dioptimalkan pengaruhnya.

Dalam proses belajar mengajar di kelas terdapat keterkaitan yang erat antara guru, siswa, dan lingkungan sosial. Guru sebagai pengajar sekaligus pendidik memegang peranan penting dan tanggung jawab yang besar dalam rangka membantu meningkatkan keberhasilan siswa yang dipengaruhi oleh kualitas pengajaran dan faktor intern dari siswa itu sendiri.

Profesi guru sebagai bidang pekerjaan khusus dituntut memiliki komitmen untuk meningkatkan mutu pendidikan. Oleh karena itu, satu keunggulan yang harus dimiliki guru adalah kreativitas (Hamzah \& Nurdin, 2011) Dalam penerapan pembelajaran berbasis aktivitas siswa, guru dituntut memiliki kreativitas dan inovatif sehingga mampu menyesuaikan kegiatan mengajarnya dengan gaya dan karakteristik belajar peserta didik (Sanjaya, 2006). Pengajar perlu kreatif dalam memilih metode dan alat pembelajaran di antara berbagai metode dan peralatan yang sesuai dengan tujuan pembelajaran. Pembelajaran yang kreatif itu akan dipandang sebagai hal yang baru oleh peserta didik atau istilah tekhnisnya sebagai suatu inovasi (Suparman, 2012).

Untuk memperoleh prestasi belajar siswa yang optimal, guru baik sebagai sumber belajar, sebagai fasilitator, sebagai pengelola, sebagai demonstrator, sebagai pembimbing, sebagai motivator dan guru sebagai evaluator dituntut untuk memiliki kreativitas yang tinggi dalam mengajar (Suparman, 2012). Dengan sistem pembelajaran yang kreatif, maka siswa akan termotivasi belajar sehingga prestasi belajarnya dapat dioptimalkan. Sejalan dengan hal tersebut Sanjaya mengemukakan bahwa untuk memperoleh hasil belajar yang optimal pula guru dituntut kreatif membangkitkan motivasi belajar (Sanjaya, 2006).

Hasil penelitian yang dilakukan oleh Adirestuty mengungkapkan bahwa kreativitas guru berpengaruh positif terhadap prestasi belajar baik secara langsung maupun secara tidak langsung melalui motivasi belajar. Bahkan diperoleh hubungan positif yang tergolong tinggi antara kreativitas guru dalam mengajar dengan prestasi belajar peserta didik (Adirestuty, 2017). 
Selain kreativitas guru dalam mengajar faktor lain yang juga mempengaruhi prestasi belajar peserta didik adalah lingkungan sosial. Lingkungan sosial yang dimaksud terdiri dari lingkungan keluarga, lingkungan sekolah, lingkungan masyarakat (Dewantara, 2010). Menurut Barnet \& Casper (2001) "human social environments encompass the immediate physical surroundings, social relationships, and cultural milieus within which defined groups of people function and interact", yang artinya bahwa lingkungan sosial manusia meliputi lingkungan fisik sekitarnya, hubungan

sosial dan lingkungan budaya yang didefinisikan sebagai sekelompok orang dengan fungsi tertentu dan saling berinteraksi.

Lingkungan sosial mempengaruhi proses peserta didik dalam belajar. Pengaruh tersebut adalah pengaruh kejiwaan yang bersifat menerima atau menolak dari peserta didik yang berakibat memperkuat atau memperlemah konsentrasi belajar. Selain itu, lingkungan sosial mewujud dalam suasana akrab, gembira dan damai atau sebaliknya mewujud dalam suasana perselisihan, bersaing, salah menyalahkan dan bercerai berai. suasana kejiwaan tersebut berpengaruh pada semangat dan proses belajar peserta didik (Dimyati \& Mudijono, 2010)

Lingkungan sosial yang pertama adalah lingkungan keluarga. Lingkungan keluarga merupakan lingkungan pertama yang diterima seorang anak dalam pendidikannya. Di dalam UU Sisdiknas No 20 tahun 2003 Bab IV pasal 7 juga disebutkan bahwa "Orang tua dari anak usia wajib belajar, berkewajiban memberikan pendidikan dasar kepada anaknya". Perhatian orangtua terhadap pendidikan yang dimaksud adalah segala bentuk usaha, dorongan, keterlibatan orangtua dalam kegiatan belajar anak baik di rumah maupun di sekolah. Keterlibatan orangtua dalam memberikan pembimbingan belajar bagi anak dan juga menyediakan fasilitas belajar terutama bukubuku pelajaran serta dorongan untuk lebih menggiatkan anak belajar. Sekolah dan rumah, dalam hal ini orang tua memiliki hubungan yang erat. Hubungan yang positif dapat dipengaruhi oleh jaringan sosial dan kelas sosial orangtua. Jaringan sosial yang dimiliki orangtua dapat mempengaruhi sikap dan kepercayaan terhadap sekolah (Kurniawan \& Wustqa, 2014)

Kedua adalah lingkungan sekolah. Lingkungan sekolah dipahami sebagai lembaga Pendidikan formal, dimana tempat inilah kegiatan belajar mengajar berlangsung, ilmu pengetahuan diajarkan dan dikembangkan kepada peserta didik (Tu'u, 2004). Chukwuemeka mendefinisikan lingkungan sekolah sebagai satu set internal fitur yang membedakan satu sekolah dari yang lain dan itu mempengaruhi perilaku staf dan siswa. Lingkungan sekolah memainkan peran penting dalam kehidupan setiap individu termasuk siswa, guru, pengusaha, atau karyawan. Secara garis besar lingkungan sekolah sangatlah berpengaruh terhadap sebuah proses pembelajaran bagi peserta didik, karena bagaimanapun lingkungan sekitar yang sengaja digunakan sebagai alat dalam proses Pendidikan (Sobri, Hanum, Zulnaidi, Ahmad, \& Alfitri, 2017)

Penelitian yang dilakukan oleh Safitri \& Kustini (2014) mengungkapkan bahwa lingkungan sekolah berpengaruh terhadap prestasi belajar ekonomi sebesar $22,85 \%$. Hal ini berarti hampir seperempat faktor yang mempengaruhi prestasi belajar dipengaruhi oleh lingkungan sekolah.

Selanjutnya lingkungan masyarakat merupakan lingkungan ketiga yang mempengaruhi prestasi belajar setelah lingkungan keluarga dan lingkungan sekolah. Peserta didik berasal dari lingkungan masyarakat dan dididik untuk hidup di dalam masyarakat oleh karena itu pengajaran yang berdasarkan lingkungan atau sumber pengajaran memberikan banyak manfaat atau nilai-nilai pendidikan bagi perkembangan dan pertumbuhan pribadi peserta didik (Tabrani \& dkk, 2000).

Menurut Woodworth yang dikutip dalam Parjiyono (2013), cara-cara individu berhubungan dengan masyarakatnya dapat dibedakan individu berhubungan menjadi empat macam yaitu: individu bertentangan dengan masyarakatnya, individu menggunakan masyarakatnya, individu berpartisipasi dengan masyarakatnya dan individu menyesuaikan diri dengan masyarakatnya. Kondisi lingkungan masyarakat tempat tinggal siswa akan mempengaruhi belajar siswa. Lingkungan siswa yang kumuh, banyak pengangguran dan anak terlantar juga dapat mempengaruhi aktivitas belajar siswa, paling tidak siswa kesulitan ketika memerlukan teman belajar, diskusi, atau meminjam alat-alat belajar yang kebetulan belum dimilikinya.

Lingkungan masyarakat yang lain adalah teman sebaya. Wang, Kiuru, Degol, \& Salmela-Aro (2018) dalam penelitiannya mengemukakan "peers become increasingly 
important socializing agents for academic behaviours and attitudes during adolescence" bahwa teman sebaya menjadi agen sosialisasi yang semakin penting dalam membentuk perilaku dan sikap akademik selama masa remaja. Dalam penelitian tersebut juga dijelaskan "students become more similar to their peers in terms of emotional, cognitive, and behavioral engagement" siswa menjadi lebih mirip dengan teman sebaya mereka dalam hal keterlibatan emosional, kognitif, dan perilaku.

Selain kreativitas guru dan lingkungan sosial, motivasi juga sangat mempengaruhi prestasi belajar peserta didik. Motivasi diperlukan karena menyebabkan, menyalurkan, dan mendukung perilaku manusia, supaya mau bekerja giat dan antusias mencapai hasil yang optimal yang dalam hal ini adalah prestasi belajar. Ormrod (2009) mendefinisikan sebagai sesuatu yang menghidupkan (energize), mengarahkan dan mempertahankan perilaku, motivasi membuat siswa bergerak, menempatkan mereka dalam suatu arah tertentu dan menjaga mereka agar terus bergerak.

Penelitian yang dilakukan oleh Yuliyatun (2012) menunjukkan bahwa motivasi belajar berpengaruh positif terhadap prestasi belajar. hasil penelitian yang sama juga dikemukakan oleh Inayah, Martono, \& Sawiji (2013). Hal ini berarti dengan meningkatkan motivasi belajar peserta didik maka pada akhirnya juga akan meningkatkan prestasi belajarnya.

Faktor-faktor yang mempengaruhi prestasi belajar yang telah disebutkan sebelumnya belum terindifikasi dengan baik di SMA Negeri 7 Soppeng. Oleh karena itu dengan tidak mengurangi peran dan fungsi faktor-faktor lain, peneliti memilih kreativitas guru, lingkungan sosial, motivasi belajar sebagai variabel penelitian. Ketiga variabel diduga mempunyai pengaruh yang cukup dominan terhadap peningkatan prestasi belajar peserta didik.

Adapun tujuan penelitian ini adalah menjelaskan bagaimana pengaruh kreativitas guru dan lingkungan sosial terhadap prestasi belajar ekonomi yang diintermediasi motivasi belajar peserta didik di SMA Negri 7 Soppeng Kabupaten Soppeng.

\section{METODE}

Penelitian ini dilakukan dengan pendekatan kuantitatif. Tujuan penelitian adalah untuk mengetahui pengaruh kreativitas guru $\left(\mathrm{X}_{1}\right)$, lingkungan sosial $\left(\mathrm{X}_{2}\right)$, dan motivasi belajar $\left(\mathrm{X}_{3}\right)$ terhadap prestasi belajar (Y) baik secara langsung maupun tidak langsung. Sesuai dengan tujuannya penelitian ini dirancang sebagai penelitian survey. Ditinjau dari pokok permasalahannya, penelitian ini dirancang sebagai penelitian orientasi dan aksi. sedangkan bila ditinjau dari dimensi waktunya, penelitian ini adalah penelitian Cross-Sectional. Ditinjau dari hubungan antar variabelnya, penelitian ini dirancang sebagai penelitian deskriptif kausalitas.

Sampel penelitian adalah peserta didik kelas X IPS, XI IPS dan XII IPS SMA Negeri 7 Soppeng sebanyak 163 orang. Sampel yang berasal dari 11 kelas dipilih dengan menggunakan tekhnik stratified random sampling berdasarkan tingkatan kelas dengan menggunakan rumus Slovin. Selanjutnya, penentuan jumlah sampel setiap kelas digunakan rumus pengambilan secara acak dengan memperhatikan jumlah peserta didik setiap kelas.

Instrumen yang digunakan dalam penelitian ini adalah kuesioner/angket dengan pernyataan tertutup. Pengumpulan data untuk variabel bebas dilakukan dengan cara memberikan angket/kuesioner kepada peserta didik sebagai responden dengan memberikan tanda pada setiap kategori pertanyaan yang disusun berdasarkan skala likert dengan 5 poin. Setiap jawaban responden akan diberikan skor dan jumlah skor menunjukkan tinggi atau rendahnya masing-masing variabel yang diukur. Jawaban sebanyak lima buah dan dijenjang pembobotan skornya, sehingga masing-masing variabel terukur menurut skala interval. Untuk variabel terikat menggunakan instrument penelitian yaitu dokumentasi nilai rapor untuk melihat variabel prestasi belajar pada mata pelajaran ekonomi.

Validasi instrumen dalam penelitian ini dilakukan dengan validitas isi dan validitas konstruk dan uji reliabilitas. Validitas isi dilakukan dengan meminta bantuan pertimbangan ahli expert judgement. Sementara validitas konstruk dilakukan untuk menguji secara empirik hubungan antar butir soal dan untuk menentukan kelompok soal yang saling menentukan sebagai suatu faktor/konstruk yang diukur melalui instrument dengan menggunakan korelasi Product moment. Reliabilitas tes berhubungan dengan kepercayaan dan keajegan hasil tes dengan menggunakan teknik Alpha Cronbach. 
Analsis deksriptif dan inferensial digunakan untuk analisis data yang telah terkumpul dengan menggunakan analisis jalur (path analysis) dengan bantuan program SPSS for windows 21 .

\section{HASIL DAN PEMBAHASAN}

Hasil uji normalitas data dengan Kolmogorov Smirnov diperoleh nilai probabilitas 0,191 lebih besar dari nilai signifikansi yang digunakan yaitu 0,05 , maka disimpulkan data berdistribusi normal. Hasil uji linearitas diperoleh nilai signifikansi pada Deviatiom from Linearity semua variabel bebas terhadap variabel terikat memiliki signifikansi lebih dari $0,05\left(X_{1}=0,389, X_{2}=0,247, X_{3}=\right.$ $0,806)$ maka semua data dinyatakan memiliki hubungan linear. Hasil pengujian multikoliniearitas diperoleh tidak terjadi multikoliniearitas dikarenakan semua nilai $r$ antarvariabel kurang dari 0,8 (korelasi $\mathrm{X}_{1}$ terhadap $X_{2}=0,650, X_{1}$ terhadap $X_{3}=0,256, X_{2}$ terhadap $X_{3}=0,430$ ). Hasil pengujian heterokedastisitas dengan uji Glejser diperoleh nilai signifikansi untuk semua variabel bebas lebih besar dari 0,05 $\left(X_{1}=0,717, X_{2}=0,579 X_{3}=\right.$ 0,118 ) maka dapat disimpulkan dalam penelitian ini tidak terjadi.

Selanjutnya, hasil analisis jalur menggunakan analisis regresi berganda dapat dilihat pada tabel berikut :

Tabel 1. Ringkasan Hasil Analisis

\begin{tabular}{cccccccc}
\hline Hipotesis & $\begin{array}{c}\text { Nilai T } \\
\left(\mathbf{T}_{\text {hitung dan }}\right. \\
\mathbf{T}_{\text {tabel }}\end{array}$ & Sig. & Beta & $\begin{array}{c}\text { Pengaruh } \\
\text { langsung }\end{array}$ & Rsquare & $\begin{array}{c}\text { Pengaruh } \\
\text { Tidak langsung }\end{array}$ & $\begin{array}{c}\text { Pengaruh } \\
\text { Total }\end{array}$ \\
\hline $\mathrm{X}_{1} \longrightarrow \mathrm{Y}$ & $-0,640<1,974$ & 0,523 & $-0,640$ & - & & 0,121 & 0,121 \\
$\mathrm{X}_{2} \longrightarrow \mathrm{Y}$ & $2,248>1,974$ & 0,024 & 0,135 & 0,135 & 0,061 & 0,153 & 0,288 \\
$\mathrm{X}_{3} \longrightarrow \mathrm{Y}$ & $2,991>1,974$ & 0,003 & 0,355 & 0,355 & & & 0,355 \\
\hline $\mathrm{X}_{1} \longrightarrow \mathrm{X}_{3}$ & $3,433>1,975$ & 0,003 & 0,341 & 0,341 & 0,186 & & \\
$\mathrm{X}_{2} \longrightarrow \mathrm{X}_{3}$ & $4,867>1,975$ & 0,000 & 0,457 & 0,457 & & & \\
\hline
\end{tabular}

\section{Pengaruh langsung kreativitas guru terhadap prestasi belajar ekonomi dan pengaruh tidak langsung kreativitas guru terhadap prestasi belajar ekonomi melalui motivasi belajar peserta didik}

Berdasarkan pada tabel 1 diperoleh hasil bahwa nilai signifikan $\mathrm{X}_{1}$ terhadap $\mathrm{Y}$ lebih dari 0,05 yaitu $0,523 / 2=0,261$ dan $T_{\text {hitung }}<\mathrm{T}_{\text {tabel }}$ maka dapat diambil keputusan $\mathrm{H}_{0}$ diterima. Artinya tidak terdapat pengaruh langsung yang signifikan kreativitas guru terhadap prestasi belajar sehingga jalur tersebut harus dihapus dari model. Nilai pengaruh langsung $\mathrm{X}_{1}$ terhadap $\mathrm{Y}$ sebesar $-0,035$ dan pengaruh tidak langsungnya sebesar 0,046 yang berarti bahwa nilai pengaruh tidak langsung lebih kecil dari nilai pengaruh langsung dan nilai signifikansi $\mathrm{X}_{1}$ terhadap $\mathrm{X}_{3}$ dan $\mathrm{X}_{3}$ terhadap $\mathrm{Y}<0,05$ Hal ini menunjukkkan bahwa secara tidak langsung $\mathrm{X}_{1}$ terhadap $\mathrm{Y}$ melalui $\mathrm{X}_{3}$ mempunyai pengaruh yang signifikan. Sehingga dalam hal ini menolak $\mathrm{H}_{0}$ dan menerima $\mathrm{H}_{1}$.

Pengaruh tidak langsung $X_{1}$ (kreativitas guru) terhadap $\mathrm{Y}$ (prestasi belajar) melalui $\mathrm{X}_{3}$ (motivasi belajar) adalah perkalian antara nilai Beta variabel $X_{1}$ terhadap $X_{3}$ dengan nilai Beta $\mathrm{X}_{3}$ terhadap Y yaitu $=0,341 \times 0,335=0,121$.
Karena tidak terdapat pengaruh langsung yang mempengaruhi kreativitas guru terhadap prestasi belajar maka perhitungan pengaruh totalnya hanya melibatkan pengaruh tidak langsung. Maka, pengaruh total yang diberikan $\mathrm{X}_{1}$ terhadap Y adalah 0,121 atau 12,1\%.

Hal ini tentu menunjukkan analisa bahwa kreativitas guru dalam mengajar diperlukan untuk meningkatkan prestasi belajar peserta didik meskipun pengaruhnya secara tidak langsung. Kreativitas guru dalam mengajar hanya berpengaruh secara tidak langsung terhadap prestasi belajar melalui motivasi belajar. Dengan kata lain, prestasi belajar bisa ditingkatkan dengan kreativitas guru jika guru lebih kreatif membangkitkan motivasi belajar siswa. Semakin kreatif guru yang mengajar maka akan semakin meningkatkan motivas belajar peserta didik dan pada akhirnya berimplikasi positif pada peningkatan prestasi belajar peserta didik.

Hal ini sesuai dengan yang dikemukakan Sanjaya (2006) bahwa untuk memperoleh hasil belajar yang optimal, guru dituntut kreatif membangkitkan motivasi belajar siswa sehingga pada akhirnya bisa meningkatkan prestasi belajarnya. Hasil penelitian ini juga konsisten dengan penelitian 
yang dilakukan oleh Adirestuty (2017) yang menunjukkan bahwa kreativitas guru berpengaruh positif terhadap motivasi belajar peserta didik dan prestasi belajar peserta didik. Penelitian yang lain yang sejalan adalah penelitian yang dilakukan Sahidah (2012) bahwa kreativitas guru berpengaruh kuat sebesar 71,4 persen terhadap prestasi belajar siswa di SMK Negeri 1 Stabat.

\section{Pengaruh lingkungan sosial terhadap prestasi belajar ekonomi dan pengaruh tidak langsung lingkungan sosial terhadap prestasi belajar ekonomi melalui motivasi belajar peserta didik}

Berdasarkan tabel 1 diperoleh hasil bahwa nilai signifkasnsi $\mathrm{X}_{2}$ terhadap $\mathrm{Y}$ kurang dari 0,05 yaitu $0,04 / 2=0,02$ dan $T_{\text {hitung }}>T_{\text {tabel }}$ $\left(\mathrm{T}_{\text {hitung }}=2,248, \mathrm{~T}_{\text {tabel }}=1,974\right)$ maka dapat diambil keputusan menolak $\mathrm{H}_{\mathrm{o}}$ dan menerima $\mathrm{H}_{1}$ yang berarti terdapat pegaruh langsung yang signifikan lingkungan sekolah terhadap prestasi belajar dan besarnya pengaruh langsung tersebut adalah 0,135 . Adapun pengaruh tidak langsung dapat dilihat dari signifikansi $\mathrm{X}_{2}$ terhadap $\mathrm{X}_{3}$ dan $\mathrm{X}_{3}$ terhadap $\mathrm{Y}$ dimana keduanya signifkansinya kurang dari 0,05 dan pengaruh tidak langsung $\mathrm{X}_{2}$ terhadap $\mathrm{Y}$ melalui $\mathrm{X}_{3}$ adalah perkalian antara nilai Beta $X_{2}$ terhadap $X_{3}$ dengan nilai Beta $X_{3}$ terhadap $\mathrm{Y}$ yaitu $0,457 \times 0,335=0,153$. Berdasarkan perhitungan maka diketahui nilai pengaruh tidak langsung lebih besar dari nilai pengaruh langsung, hasil ini menunjukkan bahwa secara tidak langsung $\mathrm{X}_{1}$ melalui $\mathrm{X}_{3}$ mempunyai pengaruh yang signifikan terhadap Y. Sehingga dapat dalam hal menolak $\mathrm{H}_{0}$ dan menerima $\mathrm{H}_{1}$ artinya terdapat pengaruh tidak langsung yang signifikan lingkungan sosial terhadap prestasi belajar melalui motivasi belajar.

Dikarenakan Maka pengaruh total yang yang diberikan $\mathrm{X}_{2}$ terhadap $\mathrm{Y}$ adalah pengaruh langsung ditambah dengan pengaruh tidak langsung yaitu $0,135+0,153=0,288$ atau $28,8 \%$.

Berdasarkan hasil analisis data, diperoleh bahwa terdapat pengaruh langsung positif yang signifikan lingkungan sosial terhadap prestasi belajar dan pengaruh tidak langsung yang positif signifikan lingkungan sosial terhadap prestasi belajar melalui motivasi belajar. Adapun pengaruh total yang diberikan variabel lingkungan sosial baik secara langsung mempengaruhi prestasi belajar siswa maupun secara tidak langsung melalui motivasi belajar adalah berpengaruh positif. Hal ini menunjukkan analisa bahwa lingkungan sosial mempunyai pengaruh yang cukup tinggi dalam meningkatkan prestasi belajar peserta didik. Lingkungan sosial merupakan lingkungan baik yang secara langsung maupun tidak langsung mempengaruhi pola pikir, sikap dan tingkah laku peserta didik dalam pembelajarannnya mempunyai andil yang bisa dibilang cukup besar dalam memengaruhi prestasi belajar baik secara langsung maupun tidak langsung. Dalam penelitian ini didapatkan pengaruh total lingkungan sosial terhadap prestasi belajar sebesar $28,8 \%$ yakni seperempat faktor yang mempengaruhi prestasi belajar dipengaruhi oleh lingkungan sosial peserta didik, sementara factor lain dianggap konstan atau tetap. Sejalan dengan hasil penelitian tersebut, bahkan dalam beberapa penelitian terdahulu yang menjadi bahan rujukan, salah satu misalnya penelitian yang dilakukan oleh Yuliyatun (2012) hasil penelitiannya menunjukkan bahwa lebih dari $50 \%$ prestasi belajar dipengaruhi oleh lingkungan sosial dan motivasi belajar.

\section{Pengaruh langsung kreativitas guru dan lingkungan sosial terhadap motivasi belajar peserta didik}

Berdasarkan hasil analisis data pada tabel 1 bahwa nilai signifikansi $X_{1}$ terhadap $X_{3}$ adalah 0,003 dan signifikansi $X_{2}$ terhadap $X_{3}$ adalah 0,000 , begitupula dengan nilai $\mathrm{T}_{\text {hitung }}$ keduanya lebih besar dari nilai $\mathrm{T}_{\text {tabek. }}$ Sehingga dalam hal ini menolak $\mathrm{H}_{0}$ dan menerima $\mathrm{H}_{1}$ dengan demikian dapat disimpulkan keduanya memiliki pengaruh langsung yang signifikan terhadap motivasi belajar,

Secara parsial, besar pengaruh langsung kreativitas guru terhadap motivasi belajar adalah 0,342 dan besar pengaruh langsung lingkungan sosial terhadap motivasi belajar adalah 0,457. Adapun secara simultan juga kreativitas guru dan lingkungan sosial secara langsung berpengaruh positif terhadap motivasi belajar. Besar kontribusi atau nilai $\mathrm{R}$ Square dari kedua variabel yaitu kreativitas guru dan lingkungan sosial terhadap motivasi belajar sebesar $18,6 \%$ sedangkan sisanya $81,4 \%$ dipengaruhi oleh faktor lain yang tidak diteliti dalam penelitian ini. Ini tentu menunjukkan pengaruh lingkungan sosial yang positif diperlukan untuk meningkatkan motivasi belajar peserta didik. Semakin baik lingkungan sosial peserta didik maka motivasinya dalam belajar akan lebih tinggi. 
Hasil penelitian ini konsisten dengan penelitian yang dilakukan oleh Supartini (2016) bahwa kreativitas guru memiliki pengaruh yang signifikan terhadap prestasi belajar peserta didik.. Hasil penelitian ini sejalan pula dengan pendapat Santrock (2007) bahwa dalam kegiatan proses belajar peserta didik, motivasi ekstrinsik yang paling kuat untuk mendorong motivasi belajarnya adalah orangtua dirumah dan guru sebagai pendidik disekolah. Di sekolah tugas seorang pendidik tidak hanya menyampaikan materi ajar yang sesuai dengan kurikulum, tetapi juga diharapkan dapat membangun motivasi belajar peserta didiknya. Hasil penelitian ini juga sejalan dengan teori oleh Sanjaya (2006) bahwa untuk memperoleh hasil belajar yang optimal, guru dituntut kreatif membangkitkan motivasi belajar siswa sehingga pada akhirnya bisa meningkatkan prestasi belajarnya.

\section{Pengaruh langsung motivasi belajar terhadap prestasi belajar ekonomi peserta didik di SMA Negeri 7 Soppeng}

Berdasarkan tabel 1 maka diperoleh nilai signifikansi pengaruh motivasi belajar $\left(\mathrm{X}_{3}\right)$ terhadap prestasi belajar $(\mathrm{Y})$ yaitu 0,003 lebih kecil dari 0,05 dan nilai $\mathrm{T}_{\text {hitung }}=2,991$ lebih besar dari nilai $\mathrm{T}_{\text {tabel }}=1,974$ dan nilai Beta adalah 0,355 sehingga disimpulkan menolak $\mathrm{H}_{0}$ dan menerima $\mathrm{H}_{1}$ yang artinya terdapat pengaruh langsung yang positif motivasi belajar terhadap prestasi belajar.

Berdasarkan hasil analisis data tersebut diperoleh bahwa terdapat pengaruh langsung yang signifikan motivasi belajar terhadap prestasi belajar peserta didik di SMAN 7 Soppeng. Pengaruh langung yang positif motivasi belajar terhadap prestasi belajar sebesar $35,5 \%$ yang merupakan nilai tertinggi pengaruh yang diberikan terhadap prestasi belajar diantara variabel lainnya (kreativitas guru dan lingkungan sosial) sedangkan faktor lain dianggap tetap atau konstan. Hasil analisis ini menunjukkan betapa motivasi belajar belajar peserta didik dalam belajar sangat dibutuhkan untuk meningkatkan prestasi belajar peserta didik.

Hasil penelitian ini sejalan dengan penelitian yang dilakukan oleh Darmawati (2017). Hasil penelitian menunjukkan bahwa Peningkatan motivasi belajar berdampak nyata pada peningkatan prestasi belajar, dan besarnya pengaruh motivasi belajar terhadap prestasi belajar adalah sebesar $16 \%$.
Penelitian lain yang konsisten dengan kajian penelitian ini yaitu yang dikemukakan oleh Sukarti (2012) bahwa motivasi belajar memiliki pengaruh positif terhadap prestasi belajar. Siswa yang memiliki motivasi yang tinggi tampil lebih baik secara secara akademis dibanding siswa dengan morivasi yang rendah. Sebagaimana yang dinyatakan oleh Tella (2007) "higly motivated students perform better academically than the lowly motivated students"

Motivasi belajar yang dimaksud adalah dorongan kuat dari dalam atau luar individu yang dapat meningkatkan performa kerja, prestasi belajar, dan hal lainnya untuk mencapai tujuan pembelajaran. Seorang peserta didik yang termotivasi dalam belajar maka akan tampak indikator-indikator seperti yang dikemukakan oleh Dimyati dan Mudjiono (2002) yaitu aktif mengikuti pembelajaran, mempersiapakan diri dengan mempelajari materi yang akan diberikan guru, aktif mengikuti diskusi atau pemecahan masalah, mengerjakan tugas yang diberikan oleh guru, memanfaatkan sumber belajar yang ada, berusaha menjawab pertanyaan-pertanyaan guru, memanfaatkan waktu-waktu luang untuk membaca atau belajar, senang terhadap tugas, serta bekerja sama dengan siswa lain. Setelah indikator-indikator tersebut tampak pada seorang peserta didik maka diharapkan prestasi belajar yang dimiliki bisa ditingkatkan atau optimal.

\section{SIMPULAN DAN SARAN}

Berdasarkan hasil peneltian dan pembahasan maka dapat disimpulkan (1) Tidak terdapat pengaruh langsung kreativitas guru terhadap prestasi belajar dan terdapat pengaruh tidak langsung yang positif dan signifikan kreativitas guru terhadap prestasi belajar melalui motivasi belajar. (2) Terdapat pengaruh langsung positif yang signifikan lingkungan sosial terhadap prestasi belajar dan pengaruh tidak langsung yang positif yang signifikan lingkungan sosial terhadap prestasi belajar melalui motivasi belajar. (3) Terdapat pengaruh langsung yang signifikan kreativitas guru dan lingkungan sosial terhadap motivasi belajar baik secara parsial maupun secara simultan. (4) Terdapat pengaruh langsung positif yang signifikan motivasi belajar terhadap prestasi belajar.

Adapun saran dalam penelitian ini kepada para pemerintah dan para pengamat pendidikan hendaknya lebih sering mengadakan seminar-seminar atau workshop yang 
bertemakan tentang kreativitas guru, lingkungan sosial yang berkaitan dengan peningkatan motivasi belajar dan prestasi belajar siswa agar menjadikan guru lebih aktif, inovatif dan professional. Kepada guru bidang studi diharapkan untuk lebih memotivassi siswa dengan menciptakan pembelajaran yang kreatif yang dapat menimbulkan minat belajar siswa, dan seorang guru juga harus meningkatkan kualitas diri dengan memberikan teladan dan bimbingan kepada para siswa. Kepada pihak sekolah agar lebih memperhatikan sarana dan prasana sekolah sebagai sumber belajar atau alat belajar yang dibutuhkan dalam proses pembelajaran, serta menciptakan lingkungan sekolah yang kondusif, nyaman, dan menyenangkan. Kepada orang tua disarankan agar lebih mengoptimalkan perannya untuk mendukung dan memotivasi anak agar lebih giat belajar dan memperhatikan keperluan sekolah anak-anaknya. Kepada para siswa agar lebih aktif dalam pembelajaran agar tercipta interaksi antara guru dengan siswa, menjaga lingkungan sekolah dan kelas yang bersih dan sehat sehingga tercipta suasana belajar yang menyenangkan.

\section{Acknowledgement}

Penelitian ini didanai penuh oleh Lembaga Pengelola dana Pendidikan (LPDP) Indonesia. Ucapan terima kasih kepada pihak Lembaga Pengelola Dana Pendidikan (LPDP) atas segala dukungan dan bantuannya selama ini serta kepada pihak SMA Negeri 7 Soppeng yang telah memberikan akses dalam melakukan penelitian.

\section{DAFTAR RUJUKAN}

Adirestuty, F. (2017). Pengaruh Self-Efficacy Guru dan Kreativitas Guru terhadap Motivasi Belajar Siswa dan Implikasinya terhadap Prestasi Belajar pada Mata Pelajaran Ekonomi. Jurnal Wahana Pendidikan, Vol. 4 no. 1, 54-67. Retrieved Januari 2019, from http;//jurnal.unigal.ac.id/index.php/jwp/ article/view/386

Aini, P. N., \& Taman, A. (2012). Pengaruh Kemandirian Belajar dan Lingkungan Belajar Siswa terhadap Prestasi Belajar Akuntansi Siswa Kelas XI IPS SMA Negeri 1 Sewon Bantul Tahun Ajaran 2010/2011. Jurnal Pendidikan Akuntansi Indonesia, Vol. 10 No.1, 48-
65. Retrieved Juli 14, 2018, from https://journal.uny.ac.id/index.php/jpak un/article/view/921

Barnet, E., \& Casper, M. (2001, March ). A Definition of "social Environment". American Journal of Public Health, Vol. 91 No. 3, 465. Retrieved Januari 2019, http://www.ncbi.nlm.nih.gov/pmc/articl e

Darmawati, J. (2017). Pengaruh Motivasi Belajar dan Gaya Belajar terhadap Prestasi Belajar Ekonomi Siswa SMA Negeri di Kota Tuban. Jurnal Ekonomi Pendidikan dan Kewirausahaan, Vol. 1 No. 79. doi:10.26740/jepk.v1n1.p79-90

Dewantara. (2010). Membangun Kepribadian dan Watak Bangsa Indonesa. Yogyakarta: Pustaka belajar.

Dimyati, \& Mudijono. (2002). Belajar dan Pembelajaran. Jakarta: Asdi Mahasatya.

Dimyati, \& Mudijono. (2010). Belajar dan Pembelajaran. Yogyakarta: Pustaka Belajar.

Hakim, T. (2008). Belajar Secara Efektif. Jakarta: Puspa Swara.

Hamzah, B. U., \& Nurdin, M. (2011). Belajar dengan Pendekatan PAIKEM : Pembelajaran Aktif, Inovatif, Lingkungan, Kreatif, Menarik. Jakarta: PT Bumi Aksara.

Inayah, R., Martono, T., \& Sawiji, H. (2013). Pengaruh Kompetensi Guru, Motivasi Belajar dan Fasilitas Belajar terhadap Prestasi Belajar Mata Pelajaran Ekonomi pada SIswa Kelas XI IPS SMA NEGERI 1 LASEM Jawa Tengah Tahun Pelajaran 2011/2012. Jurnal Pendidikan Insan Mandiri, 1-12. Retrieved Januari 14, 2018, from http://eprints.uns.ac.id/1961/1/18994276-1-SM

Kurniawan , D., \& Wustqa, D. U. (2014). Pengaruh Perhatian Orang Tua, Motivasi Belajar, dan Lingkungan Sosial terhadap Prestasi Belajar Matematika Siswa SMP. Jurnal Riset 
Pendidikan Matematika, Vol. 1, 176187. doi:10.21831/jrpm.v1i2.2674

Ormrod, J. E. (2009). Psikologi Pendidikan, Membantu Siswa Tumbuh dan Berkembang. Jakarta: Erlangga.

Parjiyono. (2013). Korelasi Faktor Keluarga dan Lingkungan Sosial terhadap Prestasi Belajar Siswa Kelas IX di SMP Negeri 4 Kudus. Universitas Negeri Sebelas Maret, Program Studi Tekhnologi pendidikan. Surakarta: UNS Institutional Repository. Retrieved from https://eprints.uns.ac.id/8084/

Safitri , F. N., \& Kustini, S. (2014). Pengaruh Minat Belajar, Kondisi Sosial Ekonomi Orang Tua, dan Lingkungan Sekolah terhadap Prestasi Belajar Ekonomi pada Siswa Kelas XI IPS SMA Negeri 4 Magelang Tahun Ajaran 2013/2014. Economic Education Analysis Journal, Vol. 3 No. 3, 249-256. Retrieved Januari 2019,http://journal.unnes.ac.id/sju/inde x.php.eeaj

Sahidah , H. (2012). Pengaruh Kreativitas Guru terhadap Prestasi Belajar Siswa SMK Negeri 1 STABAT Tahun Ajaran 2011/2012. Medan: Universitas Negeri Medan. Retrieved from http://digilib.unimed.ac.id/13106/

Sanjaya, W. (2006). Strategi pembelajaran Berorientasi Standar proses pendidikan. Jakarta: Kencana Prenada Media Grup.

Santrock, J. W. (2007). Psikologi Pendidikan. Jakarta: Kencana.

Sobri, K. M., Hanum, F., Zulnaidi, H., Ahmad, A. R., \& Alfitri. (2017). A Comparative Study of School Environment for Students' Skill Development in Malaysia and Indonesia. Kasetsart Journal of Social Sciences, Vol. 1 No. 2, 1-6. doi:10.1016/j.kjss.2017.10.002

Sudijono, A. (2011). Pengantar Evaluasi Pendidikan. Jakarta: Rajawali Pers.

Sukarti. (2012). Faktor-Faktor yang Mempengaruhi Hasil Belajar IPS Madrasah Ibtidaiyah Siswa Kelas V di Kabupaten Bantul Yogyakarta. Yogyakarta: UNY
Suparman, A. (2012). Desain Instruksional Modern. Jakarta: Erlangga.

Supartini, M. (2016). Pengaruh Penggunaan Media Pembelajaran dan kreativitas Guru terhadap Prestasi Belajar Siswa Kelas Tinggi di SDN Mangunharjo 3 Kecamatan Mayangan Kota Probolinggo. Jurnal Penelitian dan Pendidikan IPS, 277-293. Retrieved Juli 14, 2018, from https://scholar.google.co.id./scholar?hl $=\mathrm{en} \& \mathrm{as} \_\mathrm{sdt}=0 \% 2 \mathrm{C} 5 \& \mathrm{q}=$ pengaruh $+\mathrm{kre}$ ativitas+guru\&oq=pengaruh+\#d=gs_qa $\mathrm{bs} \& \mathrm{u}=\% 23 \mathrm{p} \% 3 \mathrm{Dp0dnOoHfUnAJ}$

Tabrani, R., \& dkk. (2000). Pendekatan dalam Proses Belajar Mengajar. Bandung: CV. Remadja Rosda Karya .

Tella, A. (2007). The Impact of Motivation on Student's Academic Achievement and Learning Outcomes in Mathematics Among Secondary School ini Nigeria. Eurosia Journal Pf Mathematics, Sciences \& Technology Education 2007, Vol. 3 No. , 149-156. Retrieved Desember 27, 2018, from http://core.kmi.open.ac.uk/download/pd f/512292/pdf

Tu'u, T. (2004). Peran Disiplin pada Perilaku Prestasi Siswa. Jakarta: Grasindo.

Wang, M.-t., Kiuru, N., Degol, J., \& SalmelaAro, K. (2018). Friends, Academic Achievement, and School Engangement during adolescence: A Social Network Approach to Peer Influence and Selection Effects. learning and Instruction, 148-160. doi:10.1016/j.learninstruc.2018.06.003

Yuliyatun. (2012). Pengaruh Lingkungan Sosial dan Motivasi Belajar terhadap Prestasi Belajar Ekonomi pada Siswa kelas VIII MTs AL IRSYAD Ngawi Tahun Ajaran 2011/2012. Pendidikan Ekonomi Akuntansi. Surakarta: Universitas Muhammadiyah Surakarta. Retrieved Juli 14, 2018, http://eprints.ums.ac.id/19252/ 